\title{
Mikrohistorie bałkańskie
}

\section{TOPOGRAFIA NOSTALGII JAKO TOPOGRAFIA TOŻSAMOŚCI (NA PODSTAWIE TWÓRCZOŚCI DUBRAVKI UGREŠIĆ I PAVAO PAVLIČICIA)}

\author{
BARBARA CZAPIK-LITYŃSKA ${ }^{1}$ \\ (Uniwersytet Śląski)
}

\begin{abstract}
Słowa kluczowe: nostalgia, pamięć, tożsamość, przestrzeń, miasto, perspektywa real-and-imagined, nastrój, enumeracja, ojczyzna
\end{abstract}

Key words: nostalgia, memory, identity, space, city, perspective real-and-imagined, mood, enumeration, motherland

\begin{abstract}
Abstrakt: Barbara Czapik-Lityńska, TOPOGRAFIA NOSTALGII JAKO TOPOGRAFIA TOŻSAMOŚCI (NA PODSTAWIE TWÓRCZOŚCI DUBRAVKI UGREŠIĆ I PAVAO PAVLIČICIA). „PORÓWNANIA" 12, 2013, T.XII, s. 103-116. ISSN 81733-165X. Artykuł omawia interakcje między przestrzenią ludzką (human) a literaturą. Literackie wizerunki miasta (Berlin, Amsterdam, Vukovar) reprezentują nostalgię podmiotu, jego nastroje i tęsknoty. W twórczości Ugrešić podmiot (subject) to zagubiony, samotny emigrant homo exul.. Pisarka pokazuje rzeczywistość w perspektywie real-and-imagined. Miejska przestrzeń jest obca, pogłębia alienację i samotność. Nastroje nostalgiczne wynikają z tęsknoty za ojczyzną i są dla pisarki utrapieniem. Albowiem powrót do ojczyny (Chorwacji i Jugosławii) nie jest możliwy. W twórczości Pavličicia powrót do ojczyzny (Chorwacji) jest możliwy. Moc kreacji literackiej, pamięć i wyobraźnia odnawiają (odbudowują) przestrzeń zniszczonego Vukovaru. Pisarz stosuje enumerację, tworzy wizerunki miasta zwykłego i miasta magicznego. Dyskurs nostalgiczny chorwackich pisarzy jest równocześnie dyskursem tożsamościowym.
\end{abstract}

Abstract: Barbara Czapik-Lityńska, TOPOGRAPHY OF NOSTALGIA AS TOPOGRAPHY OF IDENTITY (BASED ON THE WORKS OF DUBRAVKA UGREŠIĆ AND PAVAO PAVLIČIĆ). "PORÓWNANIA" 12, 2013, Vol. XII, p. 103-116. ISSN 81733-165X. The article describes the interactions between the human space and literature. Literary images of the city (Berlin, Am-

${ }^{1}$ Correspondence Address: barbara.czapik-litynska@us.edu.pl 
sterdam, Zagreb) represent the subject's nostalgia, its longings and moods. In Ugrešić's work the subject is a lost, lonely emigrant homo exul. The writer shows the reality from a "real-andimaginated" perspective. The urban setting is strange and deepens the alienation and loneliness. The nostalgic atmosphere comes from a longing for the motherland. The return to the motherland is impossible. In the works of Pavličić the return to the homeland is possible. The power of literary creation, memory and imagination renews the space of destroyed Vukovar. The writer uses enumeration and creates images of an unexceptional and magical city. The nostalgic discourse of Croatian writers is at the same time an identity discourse.

To co wywołuje nostalgię, owe ukłucie mglistego uczucia, jest tak samo złożone jak topografia naszej pamięci. Mechanizmy nostalgii są nieprzewidywalne i trudne do odczytania, podobnie jak mechanizm snu, w którym oniryczne zetknięcie $\mathrm{z}$ błahym i niewinnym przedmiotem może wywołać niewspółmierną emocję. (...) Trudno przewidzieć, czy pewnego dnia uda się nostalgii wyartykułować swój przedmiot i określić swoje terytorium.

Dubravka Ugrešić, Kultura kłamstwa

Dubravka Ugrešić i Pavao Pavličić należą do pokolenia chorwackich pisarzy postmodernistycznych. Uznając, podobnie jak Dubravka Oraić Tolić, że kluczową kategorią dla chorwackiej przestrzeni symbolicznej jest nostalgia i utopia ${ }^{2}$, chciałabym porównać dwa literackie doświadczenia nostalgii ponowoczesnej, które postrzegam jako doświadczenia estetyczno-antropologiczne i zarazem jako sui generis doświadczenie tożsamościowe. Temat jest nader szeroki, lecz istniejące prace umożliwiają podjęcie zagadnienia w stopniu elementarnym, zwłaszcza, że historycy literatury interpretowali już problemy zakorzenia wyobraźni obojga autorów w przestrzeni i pejzażu. W pracach slawistycznych zajmowano się literackimi reprezentacjami (i ekwiwalentyzacjami) i rzeczywistości realnej, i rzeczywistości fikcjonalnej, miasta realnego i miasta wyobrażonego, m.in. z postmodernistycznej perspektywy real-and-imagined ${ }^{3}$. Wydaje się, że ta właśnie perspektywa wnosi najwięcej informacji o specyfice i tropach nostalgicznej pamięci i nostalgicznej tęsknoty.

2 Zob. D. Oraić Tolić, Paradigme 20. stoljeća. Awangarda i postmoderna, Zagreb 1996 oraz Tejże, Muška moderna i ženska postmoderna. Zagreb 2005. W ujęciu chorwackiej badaczki (omówienie pierwszej z książek umieściłam $w$ „Pamiętnik Słowiańskim” R. 1997/1998, T. XLVII/XLVIII, s. 209-211) awangarda jest kulturą utopijną, postmodernizm - kulturą nostalgiczną. Jeżeli utopijną wyobraźnię awangardy odczytywałam kiedyś przy pomocy kategorii "jeszcze-nie" (w książce "Jeszcze-nie". Utopicum jugostowiańskiej awangardy, Katowice 1996), to nostalgiczną wyobraźnię postmodernizmu można by zapewne opisać posiłkując się kategorią ,już-nie". Nastąpił bowiem zwrot od awangardowej wyobraźni rzutującej projekty w przyszłość jako czasoprzestrzeń ich realizacji, do wyobraźni postmodernistycznej, rozpoznającej słabość tej przestrzeni, przygodność i przemijalność.

${ }^{3}$ Perspektywa real-and-imagined należy do kluczowych strategii postmodernizmu, umożliwia nie tylko oryginalne kreacje biografii miasta i jego mieszkańców, ale także intrygujące interpretacje rze- 
W chorwackiej literaturze i w chorwackiej myśli literaturoznawczej nostalgia przejawia się dwojako, w dwóch kontekstach - jako tęsknota za chorwackością (obok wariantu utopijnego, zwróconego ku słowiańskości ${ }^{4}$ ) oraz jako uniwersalna tęsknota za przeszłością, za utraconymi: wartościami, przestrzeniami, miejscami rzeczywistymi i wyobrażonymi. Nostalgia ponowoczesna wykracza poza aspekt powiązań ideologicznych, (wyjątkiem jest pojęcie jugonostalgii ${ }^{5}$ ), jest wszechobecnym elementem postmodernistycznego nastrojenia intelektualno-emocjonalnego i artystycznego, jest więc ważną kategorią estetyczno-antropologiczną. Kontekst drugi jest charakterystyczny dla literatury postmodernistycznej. U interesujących nas pisarzy obecne są obie formy nostalgii: tęsknota za bezpowrotnie utraconą ojczyzną, do której powrót ,już-nie" jest możliwy (u Ugrešić z różnych powodów) i tęsknota za ojczyną zniszczoną, do której powrót jest możliwy i jest to powrót

czywistości ponowoczesnej, jej znaków i znaczeń w perspektywie szerszej niż biograficzna, w perspektywie uniwersalnej kondycji egzystencjalnej conditio humana. Zob. Elżbieta Rybicka, Geopoetyka. W: Kulturowa teoria literatury, Główne pojęcia i problemu. Red. M. P. Markowski i R. Nycz. Kraków 2006, s. 486. W innym miejscu tego samego artykułu autorka przytacza definicję geopoetyki za K. White'm (s. 479) oraz definicję geokrytyki za B. Westphalem, dla którego "geokrytka jest poetyką „interakcji pomiędzy przestrzenią ludzką (human) a literaturą", zajmuje się badaniem interakcji pomiędzy fikcyjnymi, imaginacyjnymi (wyobraźniowymi) a geospołecznymi przestrzeniami oraz ich rolą $\mathrm{w}$ determinowaniu tożsamości kulturowych."- s. 478.

${ }^{4}$ Ten utopijno-nostalgiczny wariant tęsknoty za poszerzoną ojczyzną słowiańską wywodzi się z kosmpolitycznego czasu awangardy i tradycji Europy Środkowej. Przekonująco o utraconych wymiarach ideologicznych i kosmopolitycznych pisze zwłaszcza A. Debeljak, słoweński pisarz, którego wiersze i eseje były tłumaczone na język polski. Zob. A. Debeljak, Zmierzch idoli, (przeł. J. Pomorska). W: Nostalgia. Eseje o tęsknocie za komunizmem, red. F. Modrzejewski i M. Sznajderman. Wołowiec 2002, s. 206-241. O swojej tęsknocie z południem Debejlak powiada, że „odczuwa ją na płaszczyźnie metafizycznej, która - tego nie trzeba specjalnie podkreślać - nie ma nic wspólnego z byłą strukturą państwową. Moja tęsknota za południem nie jest nostalgią za scentralizowaną samowolą Belgradu" (s. 224) Tęsknota Debljaka za południem to tęsknota za południowosłowiańskimi pejzażami, za kulturowymi identyfikacjami, które przechodzą do pamięci lub do zapomnienia. W innym tekście Prostori kozmopolitizma Debeljak swoje rozważania o tęsknocie za środkowoeuropejskim kosmopolityzmem zderzonej z tęsknotą za lokalnym patriotyzmem, podsumowuje jednoznacznie: „Napetosti med njima ni mogoče izbrisati” („Napięć miedzy nimi nie da się zlikwidować.”, „Nova revija”, letnik XXII, november/december 2003. Inną nostalgiczną wypowiedzią jest piękny esej D. Jančara Wspomnienie o Jugosławii, w którym dyskurs nostalgicznej tęsknoty za pamięcią o wspólnych wartościach kulturowych został połączony z nostalgicznymi opisami pięknych miejsc utraconej Jugosławii. Zob. D. Jančar, Eseje. Przeł. J. Pomorska. Sejny 1999.

5 „To właśnie nieuchwytna natura nostalgii spowodowała, że władze nowych państw byłej Jugosławii ukuły termin jugonostalgia i nadały mu niedwuznaczne znaczenie. Termin jugonostalgik służy do politycznej i moralnej dyskwalifikacji, jugonostalgik to człowiek podejrzany, „wróg narodu”, ,zdrajca", osoba opłakująca upadek Jugosławii (czyli upadek komunizmu, a komunizm to "serbo-bolszewizm"!), wróg demokracji. Termin jugonostalgia należy do nowego, wojennego języka", zob.: Konfiskata pamięci. W: Nostalgia. Eseje o tęsknocie z komunizmem, op. cit., s. 263. Zob. też hasło Jugonostalgičari (chorwacki), W: K.-M. Gauß, Europejski alfabet. Tłum. A. Rosenau. Wołowiec 2008, s. 76-78. 
ocalający (u Pavličicia). Ponowoczesność łączy pojęcie nostalgii z cierpieniem i bólem, wynikającym ze straty, z niemożności powrotu do utraconych przestrzeni i minionego czasu. Kiedy „ocalający powrót "już-nie” jest możliwy, pozostaje pustka albo nostalgiczna tęsknota ${ }^{6}$. Jeśli nie jest ocalająca, to bywa empatyczna bądź wzniosła, bądź traumatyczna - według miary wyobraźni i pamięci podmiotu.

Uprzedzając dalszy wywód (a kierując się rozróżnieniem Dubravki Oraić Tolić o dwóch typach nostalgii: pierwszym akcentującym nostos, czyli powrót do domu; drugim kładącym naciska na algos, czyli ból wynikający z niemożliwości powro$\left.\mathrm{tu}^{7}\right)$, można sądzić, że dla twórczości Ugrešić znamienna będzie nostalgia eksponująca algos, czyli ból z powodu pustki powstałej w wyniku utraty ojczyzny, do$\mathrm{mu}$, dawnego modelu wartości, czyli z rozpadu całości, a dla Pavličicia nostos, czyli powrót do domu, do miasta dzieciństwa, do: ojczyzny, tradycji, tożsamości, wartości, pamięci, całości. Twórczość Ugrešić pokazuje przygodność bytu, twórczość Pavličicia jego ciągłość na przekór przygodności i traumatycznym wydarzeniom wojny. Kompozycja emigracyjnych utworów chorwackiej pisarki jest przemyślną mozaiką pozornie luźno łączonych fragmentów myśli, jest strukturą zawieszająca spójność narracji. Kompozycja późnych utworów Pavličicia jest tradycyjna, narracja linearna, a świat przedstawiony (nawet gdy fantastyczny) jest mocno zakotwiczony $w$ realiach mocnej (i słabej ) rzeczywistości rzeczy, przedmiotów, faktów.

Wstępnie sformułowane uwagi dopuszczają możliwość interpretacji topografii nostalgii jako topografii tożsamości. Dyskurs nostalgiczny Ugrešić i Pavličicia jest równocześnie dyskursem tożsamościowym. Obok dwóch rodzajów nostalgii widzimy też dwa rodzaje tożsamości. Nostalgię, podobnie jak doświadczenie czy tożsamość trudno zlokalizować8. Literaturoznawca dysponuje wszelako narzędziami umożliwiającymi lokalizację i nostalgii, i tożsamości. Najchętniej czyni to przez opisy relacji z przestrzeniami kultury, z przestrzeniami wewnętrznymi

${ }^{6}$ P. Czapliński przypomina, że „Słowo 'nostalgia' u swoich źródeł wcale jednak nie oznaczało 'tęsknoty', więcej nawet: u źródeł, czyli w języku greckim, określenie 'nostalgia' w ogóle nie istniało: zostało utworzone z dwóch słów greckich (nostos + algos) dopiero przez świat nowożytny i oznaczało 'bolesne pragnienie powrotu'. W języku greckim nie było jeszcze 'bólu': czasownik nosteo oznaczał powrócić. Ale również, co dość istotne, 'ocaleć. ‘Ocalający powrót - tak skumulować można greckie sensy 'nostalgii' (...) Dzisiejszy zakres znaczeniowy 'nostalgii' jest niepomiernie szerszy i dlatego nieco rozmyty. Słowo to oznaczać może zarówno tęsknotę za ojczyzną, jak i za czasem minionym, przeświadczenie o tym, że kiedyś było lepiej, ale i rozpaczliwą tęsknotę za ideałem nigdy nie wcielonym, świadomość, że powrót - do domu albo czasów minionych - jest niemożliwy, ale i wiarę, że najważniejsza jest tęsknota. Tu zdaje się tkwić najistotniejsza różnica znaczeniowa: greka rozumiała przez nostalgię 'ocalający powrót', współczesność widzi w niej raczej 'ocalającą tęsknotę'”, ibidem, s. 6,7 .

7 D. Oraić Tolić, Muška moderna i ...., op. cit., s. 196, 197.

8 Zob. A. Kunce, Zlokalizować tożsamość! W: Dylematy wielokulturowości. Red. W. Kalaga. Kraków 2004, s. 79-95. 
podmiotu i postaci osadzonymi w konkretnych i metaforycznych pejzażach. Zdaniem Rybickiej:

Etymologicznie topografia jako topos graphos - opis przestrzeni - ma solidniejsze uzasadnienie na gruncie literaturoznawstwa, nie tylko ze względu na długą tradycję retoryczną. We współczesnym krajobrazie myślowym topografia współgra bowiem z przeświadczeniem o literackim i kulturowym wytwarzaniu przestrzeni. Doskonale rezonuje też z innymi rodzimymi pojęciami - heterotopiami i topotropografią, toponimią i topologią, atopią i dystopią, podmiotem atopicznym i atopizacją"

Umiejscowienie nostalgii najłatwiej dostrzec w opisach przestrzeni przywoływanych (miejsca zamieszkania, miejsca podróży, wspomnienia) przez podmioty literackie oraz przez zaistniałe identyfikacje poznawczo-emocjonalne lub ich brak. U obu pisarzy dominującym miejscem lokalizacji nostalgii jest ojczyna i miasto. W interesującej nas twórczości jest to określona ojczyzna i konkretne miasto, choć jednocześnie fikcyjne, wyobrażone, niekiedy niezwykłe. Identyfikacje są niby proste, ale metaforyczna konkretyzacja utrudnia proste odczytania. Dlatego warto rozpocząć od przypomnienia elementów nostalgicznych i tożsamościowych zawartych w biografiach obu autorów, mimo że ten rodzaj wprowadzenia do tematu Dubravce Ugrešić na pewno by się nie spodobał. Pisarka nie lubi pojęcia tożsamości („W ostatnich latach ilekroć słyszę słowo tożsamość, natychmiast reaguję alergicznie. A słowo to słyszę wszędzie i stale"10. - pisze expressis verbis), co wynika z braku tolerancji dla nacjonalizmu chorwackiego, nie akceptującego identyfikacji wielotożsamościowych. Walka o tożsamość narodową i państwową przypomina jej o eskalacji konfliktów prowadzących do wojny. Tożsamość jest w jej twórczości emigracyjnej tematem nader częstym. Przez dłuższy czas odmawiała jednoznacznej identyfikacji narodowej ${ }^{11}$. Takiej identyfikacji wymaga na przykład paszport, który pojawia się jako częsty motyw w twórczości. Ugrešić pomięta i komentuje:

Przed dziesięciu laty miałam paszport z miękką, łatwo się gnącą czerwoną okładką, jugosłowiański, byłam pisarka jugosłowiańską Potem przyszła wojna i Chorwaci, nie pytając mnie, wcisnęli mi do ręki niebieski chorwacki paszport. Władze chorwackie oczekiwały od swoich obywateli gwałtownej transformacji, jakby sam paszport był jakąś magiczną pigułką. A ponieważ ze mną nie poszło łatwo, wykluczyli mnie wtedy ze

${ }^{9}$ E. Rybicka. Zwrot topograficzny w badaniach literackich. W: Kulturowa teoria literatury 2. Poetyki, problematyki, interpretacje. Red. T. Walas i R. Nycz. Kraków 2012, s. 313-314.

${ }^{10}$ D. Ugrešić, Tożsamość. W: tejże, Nikogo nie ma w domu. Przeł. D. J. Ćirlić. Kraków 2008, s. 81.

11 Zob. komentarze: Z. Łapiński, To samo inaczej. „Teksty Drugie” 1999, nr 5 (58); M. Todorova, Bałkany wyobrażone. Przeł. P. Szymor i M. Budzińska. Wołowiec 2008, s. 118-120 oraz B. Czapik-Lityńska Ponowoczesne doświadczenie narodowe. Przypadek Dubravki Ugrešić. W: Bunt tradycji - tradycja buntu, Księga dedykowana Profesorowi Krzysztofowi Wrocławskiemu. Red. M. Bogusławska i G. Szwat-Gyłybowa. Warszawa 2008. 
swoich szeregów, nie tylko literackich, ale i innych. Z chorwackim paszportem opuściłam swoją nowo zyskaną i swoją była ojczyznę i ruszyłam w świat ${ }^{12}$.

Ugrešić ruszyła $\mathrm{w}$ świat, $\mathrm{w}$ metaforyczną drogę i z tej nowej perspektywy uchodźcy będzie identyfikować obce miejsca oraz wspominać stare, opuszczone przestrzenie, będzie pamiętać i zapominać, i buntować się przeciwko rzeczywistości:

zgoda na identyfikację oznacza poparcie dla idei, że również literatura stanowi domenę geopolityczną, co pewnie bliższe jest rzeczywistości, ale nie do mnie należy wspieranie każdej „,rzeczywistości tylko dlatego, że to rzeczywistość13.

Przytoczony fragment jest pod każdym względem symptomatyczny dla pisarki, która niezmiennie tęskni za wartościami uniwersalnymi, która nie wyraża zgody na zamknięcie w klatce wartości narodowych i peryferyjnych, mimo że one również współtworzą świat wartości umiejscowionych w prawdziwej rzeczywistości. W eseju pt. Literacka geopolityka stawia pytanie „A co z tymi, którzy nie mają tożsamości narodowej? Z kosmopolityczną proletariacką intelektualna hołotą, z obrońcami europejskiej tożsamości, $(\ldots)^{14}$. Odpowiedzi nie napawają optymizmem: „literatura to przestrzeń geopolityki. Są wielkie literatury, które dźwigają rozkoszny ciężar uniwersalnych wartości i małe literatury, od których oczekuje się, że wniosą w swoim tobołku lokalne, regionalne, etniczne, ideologiczne, oraz wszelkie inne odmienności"15. Pisarka wchodzi w ton kontestatorki i wydaje się, że bardzo jej odpowiada rola krytyczki kultury.

W swojej polemicznej krytyce etycznej, za jaka można uznać Kulturę kłamstwa $\mathrm{w}$ rozdziale o elementarzu pisarka tłumaczy mechanizmy nasycania dziecięcej świadomości wyobrażeniami postulowanymi jako dobre, wartościowe i etyczne. Elementarz nauczył ją kochać ojczyznę poszerzona, czyli Jugosławię oraz Serbów i Chorwatów: „Oni też są braćmi. ‘Braterska przyjaźń przenosi góry!' Tak zapewnia mój elementarz (...) Do szkoły poszłam w 1957 roku. Dostałam wtedy paszport do galaktyki Gutenberga, ale i ten drugi, wewnętrzny, niewidoczny"16. Swoją małą lokalną ojczyznę, czyli pierwsze miejsce zamieszkania, wspomina po latach bez sentymentów:

Kutinę opuściłam, kiedy skończyłam gimnazjum i wyjechałam na Uniwersytet w Zagrzebiu. Chociaż moje gniazdo rodzinne, hometown, było oddalone zaledwie siedems. 192.

${ }^{12}$ D. Ugrešić, Co jest europejskiego w literaturze europejskiej. W: tejże, Nikogo nie ma w domu, op. cit.,

${ }^{13}$ Ibidem, s. 193.

14 Literacka geopolityka. W: ibidem, s. 210.

15 Ibidem, s. 215.

${ }^{16}$ D. Ugrešić, Kultura kłamstwa (eseje antypolityczne). Przeł. D. J. Ćirlić. Wrocław 1998, s. 25. 
dziesiąt trzy kilometry od Zagrzebia, wróciłam tam tylko raz: na obchody pięciolecia matury. Odkąd je opuściłam moje rodzinne gniazdo jest dla mnie całkowicie obojętną plama na mapie geograficznej ${ }^{17}$.

Pamięć pisarki nie obdarzy pierwszego domu większa uwagą, więc o nostalgicznych tęsknotach z pewnością nie może być mowy. Choć nie można wykluczyć, że kiedyś to puste, zapomniane miejsce zostanie wypełnione treściami wydobytymi z zakamarków pamięci lub wyobraźni. Ważniejszym miejscem zamieszkania stał się Zagrzeb, stolica Chorwacji. Tam podjęła studia. Tam zainteresowała się awangardą, współpracowała z najwybitniejszym znawcą awangardy słowiańskiej profesorem Aleksandrem Flakerem. Zagrzeb pozostanie w pamięci autorki przestrzenią ważną, ale najbardziej ukochanym miejscem będzie literatura. Młodzieńczy wybór zainteresowań w znacznym stopniu wpłynął na profil tożsamościowy pisarki. Fascynacje awangardą skierowały jej wrażliwość estetyczną ku nowoczesności, rewolcie, eksperymentom intelektualnym, tekstom oryginalnym, nowatorskim, otwartym. Awangarda wprowadziła w nowe doświadczenia kulturowo - przestrzenne, utopijne, kosmopolityczne, globalne ${ }^{18}$. Należy podkreślić, że tradycja awangardowa nie skłaniała ku nostalgii, raczej ku wyobraźni utopijnej, którą postmodernizm chorwacki aktywnie zdekonstruował.

Pierwszy etap dorosłej drogi był interesujący, bogaty w wydarzenia. Zagrzeb, Chorwacja, Jugosławia były miejscami dobrymi. Ten etap ukształtował poglądy pisarki na literaturę i kulturę w państwie wielonarodowym. Wczesna twórczość beletrystyczna pokazuje jak pisarka mierzy się z kulturą postmodernizmu i kryzysem literatury, późna - z kulturą i polityką rozpadu. Historie literatury chorwackiej podkreślają, że w Zagrzebiu powstały najlepsze powieści. Późna twórczość jest najczęściej oceniana jako słabsza, zaangażowana politycznie, wroga chorwackości. Tymczasem najlepsze artystycznie, najbardziej zaangażowane, krytyczne i etyczne teksty napisała Ugrešić po wyjeździe z Zagrzebia. Trauma wojny, rozpadu ojczyzny, niezgoda na nową nacjonalistyczną rzeczywistość naznaczyły jej twórczość polemiczną ostrością wyrazu. Ponieważ w Zagrzebiu spotykała się z niechęcią, zdecydowała się na emigrację. Opuściła swoją domową przestrzeń i swoje uczelniane środowisko. Późna twórczość notuje ślady jej pobytu w różnych miejscach, samotność, tęsknotę za utraconym domem i utraconą ojczyzną. To twórczość pokazująca życie rozbitków wojennych, losy wygnańcze, dezorientację i niezgodę na zmiany $\mathrm{w}$ opuszczonej ojczyźnie. Jest empatyczna, nostalgiczna i jugonostoalgiczna. Jest nasycona tęsknotą za ojczyzną, której już nie ma i do której powrót nie jest możliwy. Jest też znakomita pod względem artystycznym.

17 D. Ugrešić, Hometown. W: Nikogo nie ma w domu, op. cit., s. 50.

${ }^{18}$ Zob. interesujący artykuł o literackim doświadczeniu globalizacji przestrzeni w literaturze chorwackiej A. Flakera, O globalizaciji prostora hrvatske književnosti. W: Čovjek, prostor, vrijeme. Književnoantropološke studije iz hrvatske knjižeonosti. Red. D. Fališevac i Ž. Benčić. Zagreb 2006. Recenzję tej ciekawej książki opublikowałam w „Pamiętniku Słowiańskim”, tom LVIII, rok 2008, s. 77-84. 
Jak wcześniej zauważono pokazywanie miasta ponowoczesnego w metaforycznej perspektywie "real-and-imagined" mówi wiele o emocjach i wyobrażeniach. Pejzaże zewnętrzne bywają dopełnieniem pejzażu wewnętrznego podmiotu i bohaterów. Często stosowana perspektywa fikcjonalizacji rzeczywistości umożliwiła łączenie przestrzeni realnych z wyobrażonymi, mieszanie fikcji z faktami, sklejanie nowej realno-nierealnej rzeczywistości. Percepcja mieszkanki słowiańskiego południa w zderzeniu z realiami amerykańskimi ujawnia umowny i relatywny charakter znaków kultury. Amerykański fikcjonarz pokazuje jak kulturowe okulary wpływają na widzenie obcej przestrzeni, co autorka nazywa przemieszczoną percepcją ${ }^{19}$.

Na emigracji powstała (pisana w latach 1991-1995 a wydana w 2000 roku, w Polsce 2002) - w moim przekonaniu najlepsza książka - Muzeum bezwarunkowej kapitulacji. W żadnym innym tekście głos empatii, nostalgii i melancholii nie jest tak intensywny, przekonujący i traumatyczny, a konstrukcja literacka tak oryginalna. Podmiot-nomada to podmiot literatury postmodernistycznej, homo exul, wygnaniec dosłowny i metaforyczny, człowiek bez ojczyny i bez miejsca, z którym byłaby możliwa identyfikacja. Berlin, gdzie rozgrywa się akcja, jest miastem obcym, miastem rozbitym, miastem schizofrenicznie podzielonym: „W schizofrenicznym Berlinie są dwa miasta nieustannie skłócone: jedno, które pragnie zapomnieć, i drugie, które chce pamiętać" ${ }^{20}$. Berlin jest miejscem akcji i tłem dla nostalgicznych przemyśleń o rzeczywistości, którą utrwala pamięć i fotografia. Kompozycja tekstu nawiązuje do idei prywatnego albumu lub prywatnego archiwum, jest swego rodzaju układem fotografii myśli i nastrojów, kadrów pamięci, samotności, rozczarowania, smutku. Wyalienowana świadomość kreuje równie wyalienowaną przestrzeń. Narratorka jest zmęczona obcością otaczającej ją przestrzeni (ich bin müde), wie, Berlin nie może być domem czy ojczyzną ani dla niej, ani dla innych wygnańców. Wo bin ich? pyta w obcym języku i odpowiada, że w obcym mieście, „mieście mutancie”, w którym „młodzi ludzie kreują postapokalipsę"21. „Gdzieś w tyle za mną coraz bardziej blednie pejzaż mojego oszalałego kraju, tu, przed sobą, widzę schody, które prowadzą do nikąd" 22. Drzwi i schody to motyw przestrzeni onirycznej i poetyckiej. Wyobrażenie obcych miast wykazują strukturalne podobieństwo do obrazów sennych, nierzeczywistych.

Interpretując semantykę metafory Berlina, Anita Gostomska podkreśla paralelizm zachodzący między przestrzenią zewnętrzną i wewnętrzną: „Problematyczna tożsamość tego miasta $\mathrm{w}$ czasie transformacji koresponduje $\mathrm{z}$ zaburzonym poczuciem tożsamości podmiotu, rozdartego konfliktem jugosłowiańskim"23. Schizofre-

\footnotetext{
19 D. Ugrešić, Amerykański fikcjonarz. Przeł. D. Cirlić-Straszyńsk. Wołowiec 2001, s. 205.

${ }^{20}$ D. Ugrešić, Muzeum bezwarunkowej kapitulacji, op. cit., s. 286.

${ }^{21}$ Ibidem, s. 291, 292.

22 Ibidem, s. 293.

${ }^{23}$ A. Gostomska, Zagrzeb-Berlin-Amsterdam, O metaforze miasta w twórczości Dubravki Ugrešić, Miasto w kulturze chorwackiej. Urbano u hrvatskoj kultury. Red. M. Falski i M. Kryska-Mosur. Warszawa
} 2008, s. 194. 
niczne rozdarcie miasta podzielonego na wschodnie i zachodnie, aura alienacji, wyobcowania, samotności, rozpadu koreluje $\mathrm{z}$ chorwackimi przestrzeniami z krótkiego opowiadania z lat 90-tych z poczuciem traumatycznego rozbicia Jugosławii. W swoich odczuciach i wyobrażeniach pisarka nie jest osamotniona. Chorwacka przestrzeń opowiadań lat dziewięćdziesiątych jest równie apokaliptyczna, chaotyczna, nomadyczna, naznaczona apokalipsą wojenną i ogólnym kryzysem² ${ }^{24}$. Podobnie reaguje chorwacka poezja ${ }^{25}$.

Krešimir Bagić odczytuje przestrzeń urbanistyczną ponowoczesnego miasta jako

przestrzeń nowoczesnego nomadyzmu, niezasiedlenia i rozproszenia ducha. Pejzaż miejski jest jak labirynt, w którym człowiek, jeśli chce zachować osobowość, zmuszony jest do paradoksalnej samotności wśród tłumu, do rezygnacji z każdej zaoferowanej możliwości, to znaczy do akceptacji pozycji autsajdera ${ }^{26}$.

Przestrzeń miasta z twórczości Dubravki Ugrešić jest również labiryntem bez wyjścia. O Amsterdamie pisze:

Miasto, które upodabniało się do ślimaka, muszli, pajęczej sieci, labiryntu, koronki, do powieści pełnej tajemniczych rozgałęzień, to miasto przeobrażało się na mojej wewnętrznej mapie w połacie bieli, pustkę, niedopowiedzenia, w ślepe uliczki. Moja wewnętrzna mapa była rezultatem trudu naznaczonego amnezją, którego celem było wykreślenie własnych współrzędnych, trudu spacerowicza, który chce na piaszczystej plaży zostawić swój ślad. Moja mapa była imaginacyjnym przewodnikiem. Niewiele punktów pokrywało się z tą rzeczywistością 27.

Labirynt miasta i labirynt wyobrażeń, labirynt rzeczywistości i labirynt wyobraźni nigdy się nie pokrywają, raczej spotykają w kolejnej niejasnej przestrzeni snu lub marzenia. Choć „Mapy i kompas to wątła pomoc dla marzyciela, który stara się odnaleźć we własnych snach"28. Sen, marzenia, nostalgie są fikcjami nie pokrywającymi się z rzeczywistością, mimo że toczą się wokół niej. Są zawsze osobistymi kreacjami, które dzięki indywidualnej tożsamości wskazują na rzeczywistość jak na symboliczną sieć znaków, z którymi budują różnorakie relacje. $\mathrm{Z}$ przestrzenią miasta pisarka nawiązuje zatem relacje wyobraźniowe i poprzez

${ }^{24}$ Zob. E. Miedzielski, Dwie twarze prozy chorwackiej przełomu tysiacleci. Piśmiennictwo wojenne i krótkie opowiadanie. Poznań 2006.

${ }^{25}$ Zob. K. Pieniążek-Marković, "Ja" - człowiek i świat w najnowszej poezji chorwackiej (1990-2010). Poznań 2011.

${ }^{26}$ K. Bagić, Damoklesowy miecz rzeczywistości. Przeł. E. Szperlik. W: Widzieć Chorwację. Panorama literatury i kultury chorwackiej 1990-2005. Red. K. Pieniążek-Marković, G. Rem, B. Zieliński. Poznań 2005, s. 665 .

27 D. Ugrešić, Ministerstwo Bólu. Przeł. D. J. Ćirlić. Izabelin 2006, s. 40.

28 D. Ugrešić, Amsterdam, Amsterdam, w: Nikogo nie ma w domu, op. cit., s. 141. 
nie wyraża tęsknotę za ojczyzną. Pisze: "Amsterdam ma strukturę snu, sercem miasta jest gęsto spleciona pajęcza sieć" 29 . Fikcjonalizacja doświadczenia relacji z przestrzenią miasta współgra z doświadczeniem emigranckim, a

postmodernistyczne czytanie miasta określone jest przez utratę transcendentalnego znaczonego, co prowadzi do swobodnego przemieszczania znaków urbanistycznej przestrzeni. Patrząc z wnętrza systemu Derridy: 'miasto traci jakiekolwiek powody by było realne ${ }^{30}$

- konkluduje Jasmina Lukić. Przestrzeń bez punktu zaczepienia, bez „transcendentalnego znaczonego" nie może być spójna. Obojętne czy jest to przestrzeń miasta, czy przestrzeń egzystencji. I ten brak spójności pokazują nam kreowane przestrzenie, potęgując tym samym nostalgię za sensowną całością, której nie można wyrazić inaczej niż metaforycznie. Zwłaszcza, że jest tęsknotą niemożliwą do spełnienia.

Inne strategie fikcjonalizacji miasta stosuje Pavao Pavličić, kierując wyobraźnię ku nostalgii zbawczej, ocalającej. Być może różnicę w nostalgiach i w tożsamościach można wytłumaczyć przez (nie)obecność "transcendentalnego znaczonego", (nie)obecność punktu zaczepienia, dającego szansę całości sensownej. Podmiot chorwackiego pisarza generuje wyobrażenia całości w przestrzeni tradycji kultury chorwackiej. Pavličić nie przystaje na relatywizacje wartości ${ }^{31}$, na postmodernistyczny rozpad i brak wyjścia. Antidotum stanowi ocalająca wyobraźnia, która kreuje całość. Jednakże pisarz znajduje się w innej sytuacji niż Ugrešić. Jego biograficzny profil tożsamościowy i jego nostalgie są odmienne. Jego nostalgia jest ocalająca, bo powrót do ojczyny jest możliwy.

Pavličić urodził się $\mathrm{w}$ wielokulturowym mieście Vukovarze. Wielokulturowość była w Jugosławii czymś naturalnym, postrzeganym jako wartość. Przynajmniej w teorii, bo dla niektórych Vukovar był miastem nazbyt serbskim. Prowincjonalne miasteczko wydawało się zwyczajne, lecz we wspomnieniach jawi się jako niechętnie opuszczane miejsce szczęśliwego dzieciństwa. Pisarz odbył studia w Zagrzebiu, który stał się jego drugim domem, drugim miejscem zamieszkania, a później pracy na uniwersytecie. Zagrzeb uczynił miejscem akcji wielu swoich narracji. Jego pokolenie zafascynowane było fikcjami Borgesa. Pisarz chętnie wprowadzał strategie fantastyczne, co też jest cechą chorwackiej poetyki postmodernistycznej, zwłaszcza pokolenia tworzącego chorwacką prozę fantastyczną. Podczas studiów zwrócił się ku starej literaturze chorwackiej, która współtworzy

${ }^{29}$ Ibidem, s. 141.

30 „Postmodernističko čitanje grada obilježeno gubitkom transcendentalno označitelja, što dovodi do slobodnog plutanja urbanih znakowa. Promatran unutar sistema Derridaova 'grad gubi pretenzjiuju da bude 'realan'. J. Lukić, Imaginarne geografie egzila: Berlin i Rijeka kao fikcionlani toponimi u prozi Dubravke Ugrešić i Daše Drndić, w: Čovjek, prostor, vrijeme..., op. cit., s. 465.

31 Por. D. Oraić Tolić, Paradigme, op. cit., s. 11-148. 
kanon, uczy tradycji, poszanowania dla ciągłości. Podobnie jak Dubravka Ugrešić pozostał $\mathrm{w}$ środowisku akademickim i do dzisiaj pracuje na uniwersytecie $\mathrm{w}$ Zagrzebiu. Dopowiem subiektywnie, że najciekawsze powieści napisał - podobnie jak Ugrešić - w dojrzałej fazie życia. Przeważają w nich narracje o Vukovarze, z którego uczynił miasto prawdziwie nostalgiczne ${ }^{32}$. Vukovar jest bohaterem wielu opowieści i tworzy wielki temat literatury chorwackiej, także nostalgii za chorwackością. Temat wymagający szerszej i gruntowniejszej interpretacji33, gdyż odsyła nie tylko do twórczości Pavličicia, ale do obszernej literatury chorwackiej poświęconej Vukovarowi. Na szczególną uwagę zasługuje vukovarsko ratno pismo34. Cykl vukovarski Pavličicia powstał podczas oblężenia i bombardowania miasta oraz po jego upadku. Pamiętając o mieście dzieciństwa i młodości, o miejscu rodzinnym i jego tragedii, pisarze tworzą literaturę autobiograficzną, wspomnieniową, wojenną. Takie są również opowieści Pavličicia, który z rozmysłem i uwagą tworzy własny dyskurs pamięci i dyskurs nostalgii. Według Przemysława Czaplińskiego dyskurs nostalgiczny stosuje kilka technik: enumerację, czasownikowe formy wielokrotne, i gramatyczny czas teraźniejszy odniesiony do przeszłości.

Enumeracja jest dla nostalgii jednym z podstawowych - obok ewokacji nastroju - środków odzyskiwania przeszłości (...) Nostalgik jest przekonany, że jego enumeracja to słowa wyruszające $\mathrm{w}$ pościg za przeszłością. Przeszłość poręcza tutaj enumerację, w przeszłości jest zakotwiczona prawda wyliczania. Struktura przeszłości, model dostępu do niej - język tradycji albo prawidła psychiki - tworzy tedy metafizyczną składnię. Nostalgik wyliczając, odnawia życie ${ }^{35}$.

W cyklu vukovarskim enumeracja pełnia rolę specjalną. Umożliwia powrót do przeszłości, do dawnego Vukovaru. Jako technika postmodernistyczna jest też stosowana $\mathrm{w}$ celu zliczania rzeczy ${ }^{36}$, tak by uchronić je przed zagładą. W powieści Nevidljivo pismo z 1993 roku, podmiot literacki na przekór Dunajowi, którego wody zalewają i niszczą dom, na przekór nieuniknionej katastrofie przygotowuje spis rzeczy skazanych na zagładę. Ten dokument poświadczający realność rzeczy i przedmiotów jest zapisem pamięci nostalgicznie ratującej rzeczy przed ostatecznym zapomnieniem:

32 Zob. B. Czapik-Lityńska, Vukovar - miasto nostalgiczne. Literackie obrazy pamięci i zapomnienia w twórczości Pavla Pavličicia, w: Miasto w kulturze chorwackiej..., op. cit., s. 171-181.

${ }^{33}$ Odsyłam do polskich artykułów o Vukovarze i o twórczości Pavličicia: M. Dyras, Figury losu chorwackiego w cyklu "vukovarskim" Pavlao Pavličicia. W: Przemiany w świadomości i kulturze duchowej narodów Jugosławi po 1991 roku. Red. J. Kornhauser. Kraków 1999; B. Filuciak, Vukovarskie impresje. Miasto w prozie autobiograficznej Pavao Pavličicia. „Pamiętnik Słowiański” LVII, 2008, s. 53-75.

${ }_{34}$ Zob. G. Rem. Slavonsko ratno pismo. Osijek, Slavonski Brod, Vinkovci 1997.

35 P. Czapliński, Wznioste tęsknoty. Nostalgie..., op. cit., s. 31

36 Zob. H. Janaszek-Ivaničkova, Nowa twarz postmodernizmu, Katowice 2002, s. 90-91; W. Rusinek, O podmiotowości melancholijnej w prozie Andrzeja Stasiuka, w: Z dziejów podmiotu i podmiotowości w literaturach stowiańskich XX wieku. Red. B. Czapik-Lityńska i M. Buczek. Katowice 2005, s. 129-136. 
Spisywałem rzeczy w najważniejszym w mym życiu domu, spisywałem właściwie i całe swoje dotychczasowe życie (...) Musiałem w gruncie rzeczy spisywać bardziej ze względu na siebie, niż z myślą o jakiejś ochronie dobytku lub po to, by po prostu pozostał dokument świadczący o tym, co niegdyś było na tym wzgórzu. Musiałem sporządzać spis, aby móc zrozumieć ${ }^{37}$.

Technika enumeracji potwierdza nostalgię jako tęsknotę za minioną a utraconą przeszłością oraz jako dawanie świadectwa rzeczywistości, utrwalanie jej i przechowywanie w pamięci i w zapisie słownym. Można pójść dalej i przypisać enumeracji aspekt kreacyjny, powołujący do życia to, co odeszło w niebyt lub w zapomnienie. W tym kontekście cykl vukovarski jest w całości enumeracją, spisywaniem odchodzącego w niebyt Vukovaru, nostalgiczną tęsknotą za odnowieniem rzeczywistości, której już nie ma. Literackie powroty Pavličicia do Vukovaru to wędrówki śladami pamięci i nieistniejącej już całości.

Cykl vukovarski to cykl wspomnieniowy, łączący elementy prozy autobiograficznej z prozą rzeczywistościową, fikcję z autofikcją i elementami fantastycznymi. Obejmuje takie powieści jak: Trg slobode (1986, pol. tłum. Plac Wolności, 1986), Dunav (wyd. 2 dopełnione Sedam vukovarskih razglednica, 1992), Diksilend (1995), Šapudl (1995), Kruh i mast (1995), Vodič po Vukovaru (1997). Centralnym miejsce opowieści jest Vukovar, którego przestrzeń kształtuje pamięć, wyobraźnia, wspomnienia, obrazy, fikcje, doświadczenia autobiograficzne i nostalgia. Autor korzysta z technik postmodernistycznych, wśród których na pierwszy plan wysuwa się fikcjonalizacja realnej rzeczywistości, enumeracja, kreowanie nastroju tajemniczego i niezwykłego. Jak sam przyznaje: „Kiedy stałem się pisarzem, zyskałem możliwość czynienia z Vukovaru miejsca mitycznego, mogłem go wywyższać i w tym przesadzać, a nikt nie mógł sprawdzić, w jakim stopniu wymyślam, a w jakim daję świadectwo. Było to dobre dla Vukovaru i mojego lokalnego patriotyzmu. Czy było dobre dla literatury, to już inne zagadnienie" 38 . Dzisiaj nie mamy wątpliwości, że wraz z cyklem vukovarskim literatura chorwacka otrzymała najpiękniejsze opowieści o Vukovarze, że pisarz stworzył mit rodzinnego miasta i metaforę odrodzonego miasta/ojczyzny. Nostalgiczny powrót do miasta dzieciństwa okazał się powrotem ocalającym, ocalająca tęsknotą. A dyskurs memorialny przekształcił się niespodziewanie w dyskurs nostalgiczny.

Dyskurs memorialny Pavličicia zawiera autorski słownik memorialny, składający się ze słów kluczy do elementów świata przedstawianego - odchodzących rzeczy, ludzi, krajobrazów. Słowa memorialnego słownika mają moc nazywania, przypominania, kreowania bytu zwyczajnego i nadzwyczajnego. Mają moc magicznej rekreacji i mitycznej odnowy. Nostalgia staje się elementem zaczarowanej aury odnalezionej całości. W Dunaju oraz w książkach Šapudl i Kruh i mast dyskurs

\footnotetext{
37 P. Pavlicić, Nevidljivo pismo. Zagreb 1993, s. 59.

38 P. Pavličić, Dunav. PS. 1991. Vukovarske razglednice. Zagreb 1999, s. 207.
} 
memorialno-nostalgiczny budowany jest przy pomocy obrazów (migawek pamięci), widokówek (fotografii), albumów (archiwum pamięci) przy pomocy katalogizacji/enumeracji, obrazowania ejdetycznego, kompozycji symetrycznej (charakterystycznej dla opowieści mitycznej i fantastycznej39).

Obok Vukovaru autobiograficznego, reaktywowanego z obszarów pamięci, jest też Vukovar mityczny. W powieści Diksilend jawi się jako miasto magiczne, wypełnione niezwykłymi wydarzeniami. Wywołuje je ekscentryczny profesor Angelus, muzyk i kompozytor, który wraz z siódemką przyjaciół założył zespół dixielandowy. Wsłuchiwanie się $\mathrm{w}$ jego młodzieńczą absolutnie doskonałą kompozycję prowadziło do śmierci. Mając tego świadomość, Angelus dokonuje wyboru etycznego. Posiłkując się improwizacją, doprowadza do destrukcji doskonałej kompozycji. Śmierć struktury estetycznej jest konieczna, by przeciwstawić się śmierci człowieka. Improwizacja, prawdziwie wolny akt twórczy, wydaje się ważniejsza od formalnej doskonałości estetycznej, jeśli ta nie służy człowiekowi. Powieść kończy się przesłaniem:

Wszystko, co napisałem, pragnęło być improwizacją, ucieczką przed śmiercią. Nie wiem, czy mi się to udało. Ale wiem, że było wszystkim, czego pragnąłem i czego kiedykolwiek zapragnę. Więc muszę próbować. Jestem to winny staremu Angelusowi i wszystkim innym. A i Vukovarowi. Te moje papiery - ta moja cicha muzyka są zbyt słabe, by zmartwychwstał; dlatego one pragną jedynie zachować nadzieję, że pewnego dnia, jeśli my, którzy ocaleliśmy, spotkamy się, jeśli zagramy dobrze i z wiarą, przywrócimy życiu nasze miasto, a to znaczy i siebie ${ }^{40}$.

Przytoczone słowa wyrażają nadzieję, że utopijna energia słowa i literatury posiada moc ożywczą, a właściwie (etycznie) wykorzystana może pomóc człowiekowi i życiu. Literacka wizja Vukovaru, czy to rzeczywistego, czy fantastycznego, odwołuje się do doświadczeń podmiotu twórczego, a jednym $\mathrm{z}$ nich jest literacka i biograficzna tęsknota za miastem dzieciństwa, zrujnowanym w wojnie domowej.

Nostalgia czyni ważnymi najzwyczajniejsze rzeczy. Zwykłe słowo zmienia $\mathrm{w}$ zaczarowane, a zwykłą ulicę $\mathrm{w}$ niezwykłą przestrzeń arkadyjskiego pejzażu dzieciństwa. Autor dobrze zna granicę między możliwym i niemożliwym. Do podwórza dzieciństwa - z powieści Šapudl - prowadzą drzwi, które wystarczy otworzyć, by dokonało się przejście. Motyw drzwi wprowadza znaczenia symboliczne i mityczne. Drzwi to próg, ale i granica. W poezji bywają granicą magiczną, podobnie jak w przestrzeni fantazji. Jeśli zawierzyć autorowi, zamierzał on zakończyć Šapudl slowami „I jestem spokojny, ponieważ wiem, że pewnego dnia jednak otworzę drzwi"41. Tymczasem wydarzenia wojenne wymusiły inny Epilog:

\footnotetext{
39 P. Czapliński, Wzniosłe tęsknoty, op. cit., s. 31.

40 P. Pavličić, Diksilend. Zagreb 1995, s. 366.

${ }^{41}$ P. Pavličić, Šapudl. Zagreb 1995, s. 184.
} 
Nigdy nie otworzę drzwi w Šapudlu, (...) Vukovar był dla mnie w całości Šapudlem, tak go odczuwałem, ale już go nie ma, tak jak nie ma i Šapudla. Właśnie w czasie pisania tej ksiązki zniknął. Zacząłem pisać dlatego, że na mojej ulicy - tak jak i w moim mieście - nigdy nic ważnego się nie zdarzyło, pragnąłem i miasto, i ulicę uczynić ważniejszymi dzięki mojemu pisaniu. Teraz jest inaczej: wobec tego, co zdarzyło się na mojej ulicy i w moim mieście, wszelkie pisanie jest bez znaczenia ${ }^{42}$.

Zwątpienie w skuteczność i sensowność pisania jest przejściowe, bo w kolejnych książkach autor przeciwstawi się przygodności bytu i powróci do słów i rzeczy jako nośników sensu. Powróci do języka nostalgii i do tęsknoty za sensem.

Przedstawione $\mathrm{w}$ artykule indywidualne sposoby doświadczania nostalgii i sytuowania jej w realiach własnych światów są różne, tak jak różne są tożsamości pisarzy, wybory estetyczne i aksjologiczne, jak różne są ich wyobrażenia o kulturze i o patriotyzmie (ten wątek pozostawiamy do innego artykułu). Pisarzy łączy przynależność pokoleniowa, postmodernistyczny horyzont epistemologiczny i zamiłowanie do literatury. Dla obojga nostalgiczna tęsknota do ojczyny jest inspiracją dla pogłębionej refleksji o bycie i egzystencji ludzkiej. Dla Dubravki Ugrešić pamięć o ojczyźnie jest raczej nostalgicznym utrapieniem, tęsknota nie jest ocalająca i nie łączy się z i powrotem, dla Pavličicia pamięć o ojczyźnie jest powrotem ocalającym. Dla obojga jest źródłowym locum podmiotowości. W etycznej refleksji i w etycznej krytyce wraca zdekonstruowany przez postmodernistów podmiot. Jest to podmiot etyczny. I może tęsknota za nim jest najprawdziwszą i najbardziej wartościową nostalgią twórczą.

42 Ibidem, s. 185. 